\title{
Transformação genética: estratégias e aplicações para o melhoramento genético de espécies florestais
}

\author{
Genetic transformation: strategies for forest species breeding
}

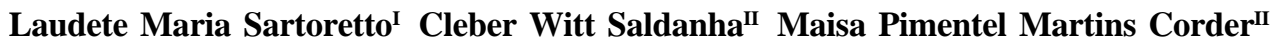

\section{- REVISÃo BIBLIOGRÁFICA -}

\section{RESUMO}

A transformação genética, que consiste na introdução controlada de um gene no genoma de uma célula receptora e em sua posterior expressão, assume adicional significância, pois abre novas perspectivas ao melhoramento genético de espécies florestais, disponibilizando novos genes com características desejáveis para serem incorporados em menor espaço de tempo. Através do uso de estratégias com Agrobacterium e biobalística, já foram obtidas plantas transgênicas com maior produção de biomassa, melhor qualidade de madeira, maior resistência a determinados insetos e com tolerância a herbicidas, entre outras características de interesse. Tais exemplos demonstram a relevância dessas ferramentas para o setor florestal. Esta revisão apresenta, de forma resumida, a importância do estabelecimento de um eficiente sistema de regeneração in vitro, as principais estratégias usadas na transformação genética de espécies florestais e algumas das características agroflorestais que já foram incorporadas nessas espécies.

Palavras-chave: biotecnologia, engenharia genética, plantas transgênicas.

\section{ABSTRACT}

The genetic transformation which consists in a controlled introduction of a gene in the genome of a receive cell and its subsequent expression, assumes additional significance, giving new perspectives to genetic improvement of the forest species, extending and available new genes with desirable characteristics, to be incorporated in a smaller period of time. Through the strategies Agrobacterium and bioballistic, transgenic plants had already been obtained showing higher biomass production, better wood quality, resistance to some insects, tolerance to herbicides, among other desirable characteristics, showing the relevance of these tools to the forest industry. This revision points out in a summarized way, the importance of establishing an efficient in vitro regeneration system, the strategies used in the genetic transformations of forestry species and some agroforestry characteristics that were previously incorporated in these species.

Key words: biotechnology, genetic engineering, transgenic plants.

\section{INTRODUÇÃO}

A atividade florestal no Brasil tem significativa importância econômica e social, disponibilizando uma ampla gama de produtos comerciais como papel, celulose, madeira serrada, compensada, laminada, painéis de fibras (TZFIRA et al., 1998; MORA \& GARCIA, 2000), resinas, óleos essenciais, frutos e mel (CARPANEZZI, 2000). Esses produtos que contribuem direta e indiretamente na geração de mais de dois milhões de empregos, desempenhando papel essencial na qualidade de vida da população (FERREIRA \& GALVÃO, 2000).

Após o período em que predominou o extrativismo na exploração das florestas nativas, em meados do século XX, teve início a pesquisa voltada para a silvicultura. Esta objetivou a produção de madeira para atender à demanda, devido à devastação da vegetação à demora na reposição com base em espécies nativas. Assim, a nova silvicultura baseava-se em espécies exóticas, principalmente dos gêneros Pinus e Eucalyptus (FERREIRA \& SANTOS, 1997).

INiceberry Frutas e Grãos do Brasil Ltda, Linha Simon s/n, 89760-000, Itá, SC, Brasil. E-mail: 1sartoretto@niceberry.com. Autor para correspondência.

"Laboratório de Biotecnologia Florestal, Universidade Federal de Santa Maria (UFSM), Santa Maria, RS, Brasil. 
Atualmente, o Brasil situa-se entre os 10 maiores países em florestas plantadas do mundo, contando com 6,4 milhões de hectares. Destes, cerca de 4,8 milhões de hectares estão florestados com pínus e eucalipto (JUVENAL \& MATTOS, 2002). Até 2010 está previsto um acréscimo no plantio anual de 152 mil hectares, o que representa um adicional de $41 \%$ em relação aos plantios realizados no período de 1995 a 2000. Esses plantios estarão concentrados nos Estados de São Paulo, Bahia, Espírito Santo, Amapá, Minas Gerais, Pará, Paraná, Santa Catarina, Mato Grosso do Sul e Rio Grande do Sul (BACHA \& BARROS 2004). Em 2001, o setor florestal gerou receitas da ordem de US\$ 21 bilhões, com destaque a três setores: madeira e móveis (US\$ 9,3 bilhões), celulose e papel (US\$ 7 bilhões), siderurgia e carvão vegetal (US\$ 4,2 bilhões), participando com 4\% no PIB nacional. Em relação às exportações, participou com cerca de $10 \%$ do valor total, contribuindo com 5,8 bilhões de dólares ao ano (LADEIRA, 2002). Tendo em vista a importância econômica das espécies florestais desde então, árvores maduras com características fenotípicas desejáveis vêm sendo selecionadas ao longo do tempo e incorporadas em programas de melhoramento, visando à obtenção de genótipos mais produtivos (GARTLAND et al., 2003). Embora esses programas tenham contribuído de forma expressiva para o aumento da produtividade no setor florestal, os mesmos têm esbarrado em limitações conseqüentes de características intrínsecas a essas espécies, destacando-se o longo tempo necessário para as plantas atingirem uma estabilidade fenotípica e maturidade reprodutiva, dificuldade de controle nos cruzamentos entre espécies, baixa variabilidade genética, entre outras (DIOUF, 2003; POUPIN \& ARCEJOHNSON, 2005).

Em decorrência dos problemas expostos, na década de 80 , as técnicas biotecnológicas vieram juntar-se ao melhoramento genético convencional, permitindo a obtenção de genótipos com maior produtividade e qualidade. Dentre essas técnicas, destaca-se a transformação genética, a qual consiste na introdução controlada de um gene ou fragmento de DNA no genoma de uma célula receptora e sua posterior expressão (DIOUF, 2003).

Dessa forma, a transformação abre novas perspectivas aos programas de melhoramento, ampliando e disponibilizando novos genes para determinadas características impostas pela incompatibilidade sexual ou pela variabilidade genética. Esses genes podem ser introduzidos em cultivares ou genótipos já melhorados, sem modificar a estrutura genética global da planta (STUDART-GUIMARÃES et al., 2003). Nesse contexto, a transformação genética, aliada à técnica de cultura de tecidos vegetais, obteve avanços consideráveis nestes últimos anos. De acordo com a FAO (2004), mais de 210 ensaios de campo estão sendo conduzidos em 16 países, envolvendo aproximadamente 15 espécies. Destas, o gênero Populus é o mais estudado com 51\% dos ensaios, seguido pelo Pinus, com 23\%, pelo Liquidambar, com $11 \%$ e o pelo Eucalyptus, com 7\%. A maioria destes (64\%) estão sendo avaliados nos Estados Unidos, seguidos pela França e Finlândia, na Europa. Das modificações genéticas reportadas em árvores, aproximadamente a metade está relacionada ao método de transformação ou a questões de biologia básica. Dos ensaios remanescentes, $13 \%$ avaliam a tolerância a herbicidas, $12 \%$ resistência biótica, $9 \%$ a química da madeira e $6 \%$ o estudo de fertilidade. Hoje, as características em foco são: aumento na densidade da madeira, redução e modificações no conteúdo e tipo de lignina e aumento no conteúdo da celulose. No Brasil, testes no âmbito de campo estão sendo conduzidos nos Estados de Minas Gerais e São Paulo, com eucalipto contendo gene de tolerância a herbicida. Até o momento, somente a China tem reportado a liberação de plantio em escala comercial de Populus transgênico, com 1,4 milhões de plantas estabelecidas a campo no ano de 2003 (VALENZUELA et al., 2006).

Cultura de tecidos: pré-requisito para a transformação genética

A cultura de tecidos vegetais pode ser definida como a manutenção, propagação e regeneração de certas partes da planta (células ou tecidos) em um ambiente livre de microrganismos (assépticas) e em condições controladas (in vitro), constituindo uma das áreas de maior êxito da Biotecnologia (MROGINSKI et al., 2004).

As diferentes técnicas de cultura de tecidos são hoje utilizadas visando a solucionar problemas em diferentes segmentos da área agrícola e florestal (GIRI et al., 2004). Em programas de melhoramento florestal, a propagação vegetativa in vitro, também denominada de micropropagação (multiplicação de gemas axilares ou apicais), tem especial destaque porque permite a manutenção e multiplicação rápida de mudas, a partir de um genótipo superior, em períodos de tempo e espaço físico reduzidos, além de assegurar um material livre de patógenos.

No processo de transformação genética, é importante ressaltar que somente um pequeno número de células-alvo recebem e integram de forma estável o DNA exógeno, sendo necessário, para a recuperação das células transformadas, o uso de um eficiente sistema de seleção e regeneração (BIRCH, 1997). O 
sucesso da regeneração in vitro baseia-se na potencialidade que as células vegetais têm de diferenciar-se originando um indivíduo (totipotência) e do controle da morfogênese, a qual é influenciada por vários fatores como tipo de explante, componentes nutricionais, reguladores de crescimento e condições de incubação (GIRI et al., 2004). Assim, o desenvolvimento de um protocolo de regeneração a partir de uma única célula, associado à escolha de genótipos mais responsivos in vitro, constituem fatores determinantes no sucesso da técnica em espécies arbóreas (PASQUALI \& ZANETTINI, 2007).

Estratégias para obtenção de plantas transgênicas O estabelecimento de um eficiente sistema de transformação para qualquer espécie vegetal necessita de três etapas: (a) identificação, isolamento e introdução do DNA exógeno na célula; (b) seleção e crescimento das células transformadas; e (c) estabelecimento de um sistema simples e eficiente de regeneração das células transformadas (BRASILEIRO \& DUSI, 1999), além da praticidade, reprodutibilidade e eficiência (HANSEN \& WRIGHT, 1999).

Para selecionar as células transformadas, além dos genes de interesse, genes marcadores de seleção são também utilizados. Estes genes conferem às células transformadas resistência a determinados agentes seletivos, como antibióticos ou herbicidas. $\mathrm{O}$ gene marcador de seleção é usado para identificar as células geneticamente modificadas, sendo que os mais utilizados são: o gene neo ou npt II (HERRERAESTRELA et al., 1983), que codifica a enzima Neomicina Fosfotransferase II (NPT II) e confere resistência a diferentes antibióticos aminoglicosilados (NORELLI \& ALDWINKLE, 1993) e o gene aroA, que codifica a enzima Sintase do 5-enolpiruvinil-3-fosfochiquimato (EPSP Sintase) de forma alterada, conferindo resistência ao herbicida glifosato (COMAI et al., 1983). Somados aos genes de seleção, as células e os tecidos transformados podem ser identificados pela expressão de genes repórteres ou marcadores, que codificam proteínas, geralmente de atividade enzimática cujo produto é facilmente detectável. Em espécies florestais, os genes repórteres mais utilizados são o gene uidA ou gus, que codifica a enzima ß-Glucuronidase (GUS) (JEFFERSON et al., 1987), e o gene gfp, que codifica a Green Fluorescent Protein(GFP) (CHALFIE et al., 1994).

Atualmente, diferentes sistemas para a transferência de genes em plantas estão disponíveis. Dentre estes, pode-se destacar o método indireto, baseado na patogenicidade de Agrobacterium, e os métodos diretos, os quais dispensam o uso de vetor intermediário (BABU et al., 2003). Hoje, os métodos de transformação de plantas utilizados com maior freqüência e eficiência são baseados nos sistemas Agrobacterium e biobalística (BRASILEIRO \& CANÇADO, 2000; STUDART-GUIMARÃES et al., 2003).

\section{Estratégia via Agrobacterium}

Agrobacterium tumefaciens é o agente causal da galha-da-coroa (do inglês crown gall), doença que se caracteriza pelo crescimento de tumores na junção entre o caule e a raiz (coroa). A formação desses tumores é o resultado de um processo natural de transferência de genes contidos em uma região específica do plasmídio Ti (tumor inducing), denominada T-DNA (transferred DNA) (ZUPAN et al., 2000; ANDRADE et al., 2003).

É sabido que nenhum gene presente na região- $\mathrm{T}$, exceto as seqüências repetidas de $25 \mathrm{pb}$, conhecidas como extremidades direita e esquerda, é necessários para o processo de transferência e integração da fita-T no genoma das células infectadas. Sendo assim, a preparação de uma linhagem de Agrobacterium para ser utilizada como vetor no processo de transformação de plantas inclui duas etapas. Na primeira, deleta-se os oncogenes, obtendose uma linhagem "desarmada”. Na segunda, preparase o vetor contendo, entre as extremidades da região$\mathrm{T}$, os genes de interesse.

Os vetores usados para a transformação de plantas pelo sistema Agrobacterium podem ser do tipo binário ou co-integrado (LACORTE \& ROMANO, 1998). No sistema binário, a região-T contendo os genes de interesse é clonada em pequenos plasmídios (10 a $30 \mathrm{~kb}$ ), que se replicam tanto em Escherichia coli quanto em Agrobacterium e se mantêm de forma independente do plasmídio Ti. Vetores binários são menos estáveis em Agrobacterium do que os plasmídios co-integrados, embora sejam de mais fácil manipulação genética (LACORTE \& ROMANO, 1998; BRASILEIRO \& DUSI, 1999). No sistema co-integrado, o plasmídio contendo os genes de interesse é integrado ao plasmídio Ti por um processo de recombinação simples. Embora estes vetores apresentem alta estabilidade em Agrobacterium, eles são pouco utilizados, pois a freqüência com que o evento de recombinação ocorre é muito baixa (BRASILEIRO \& DUSI, 1999).

O estabelecimento de uma estratégia eficiente para a transferência de genes usando o sistema Agrobacterium é dependente do sucesso da interação entre o patógeno e a planta. De acordo com TZFIRA \& CITOVSKY (2000), a primeira etapa é o reconhecimento e a fixação da bactéria no tecido 
vegetal. Na segunda, ocorre o processo de transferência do T-DNA e, finalmente, a integração do T-DNA no genoma da célula vegetal (GELVIN, 2000; ANDRADE et al., 2003). Dessa forma, a execução de todas essas etapas é necessária para a obtenção in vitro de uma planta transgênica.

A primeira espécie florestal transformada via Agrobacterium foi o híbrido de álamo Populus alba $\mathrm{x}$ Populus grandidentata, por FILLATTI et al. (1987) e, desde então, numerosos protocolos vêm sendo estabelecidos e otimizados para diferentes espécies florestais (Tabela 1).

\section{Estratégia via Biobalística}

A aceleração de partículas, também conhecida como biobalística ou bombardeamento, foi descrita inicialmente por KLEIN et al. (1987) e SANFORD et al. (1987), podendo ser definida como a introdução de moléculas de DNA em células vegetais intactas, através da utilização de microprojéteis acelerados a alta velocidade. Esse sistema consiste em quebrar a barreira da parede celular e da membrana plasmática para a livre penetração do DNA na célula. Assim, qualquer tecido com potencial de regeneração é adequado para a transformação genética através desta técnica.

Os microprojéteis de ouro ou tungstênio carreando o DNA são impulsionados por um aparelho denominado acelerador de partículas ou bombardeador, o qual gera uma onda de choque com energia suficiente para deslocar esses microprojéteis em direção ao tecidoalvo. A onda de choque pode ser gerada por ar, pólvora, eletricidade ou gás hélio. Os sistemas que utilizam gás hélio são atualmente os mais utilizados, tendo sido responsáveis pela quase totalidade das plantas transgênicas obtidas para as diferentes espécies vegetais pelo sistema biobalístico (RECH \& ARAGÃO, 1998). Em espécies florestais, a primeira metodologia de transformação usando o bombardeamento foi descrita para coníferas da espécie Picea glauca (ELLIS et al., 1993). Desde então, numerosos protocolos vêm sendo estabelecidos, visando à transformação genética de espécies florestais (Tabela 1).

Características-alvo para a transformação genética de espécies florestais

A introdução controlada de genes exógenos em plantas tem se tornado uma técnica importante tanto na área de pesquisa básica quanto para a introdução de características agroflorestais de importância econômica (TZFIRA et al., 1998). Dentre estas, podemse destacar: produção de biomassa, manipulação da composição de lignina, resistência a insetos, tolerância a herbicidas, controle do florescimento e fitorremediação (HALPIN \& BOERJAN, 2003).

a) Produção de biomassa

Para a indústria madeireira, a alta produtividade relacionada ao aumento da taxa de crescimento, ao volume do tronco e à qualidade da madeira das espécies florestais são características economicamente importantes e desejáveis para a obtenção de celulose e papel. Todavia, a fase de crescimento e desenvolvimento das plantas é regulada por hormônios vegetais, especialmente pelas giberelinas, as quais desempenham papel-chave neste processo. Dessa forma, a manipulação ou modificação dos níveis destes hormônios nas células vegetais implica o conhecimento do seu modo de ação. A manipulação de hormônios em árvores e a sua aplicação econômica foram demonstradas por ERIKSSON et al. (2000). Esses autores superexpressaram um gene isolado de Arabidopsis, o qual é essencial na via de biossíntese da giberelina (GA), que codifica para a GA 20-oxidase, em plantas transgênicas do híbrido Populus tremula x $\boldsymbol{P}$. tremuloides. As plantas obtidas como resposta deste processo de transformação apresentaram maior crescimento em diâmetro e altura, folhas maiores, fibras do xilema mais numerosas e maiores e, conseqüentemente, aumento da produção de biomassa. Segundo STRAUSS et al. (1995), outra estratégia que provavelmente resultaria em um aumento da produção de madeira em espécie florestal de importância econômica seria induzir a esterilidade via transformação genética. Por outro lado, DUNWELL et al. (2000) sugerem como estratégia para o aumento da biomassa a superexpressão de genes ligados à fotossíntese e à via da biossíntese da celulose.

b) Manipulação da composição de lignina

Na biosfera, a lignina encontra-se como o segundo composto orgânico mais abundante, antecedido pela celulose, correspondendo 15 a 35\% da madeira seca e a $25 \%$ da biomassa global (BAUCHER et al., 2003). Importante componente das plantas vasculares, a lignina ocorre em altas quantidades na parede secundária das células, sobretudo das fibras, dos vasos e traqueídeos do xilema, atribuindo às plantas suporte mecânico e defesa contra patôgenos (TZFIRA et al., 1998; DIOUF, 2003). É formada pela polimerização oxidativa de três precursores monoméricos, quais sejam, hidroxicinamílico $p$ caumárico, sinapílico e coniferílico, também chamados de monolignóis, os quais formam respectivamente as subunidades Hidroxifenil (H), Sinapil (S) e Guaiacil (G), que compõem a lignina (GIRI et al., 2004; DEAN, 2005). 
Tabela 1 - Transformação genética em espécies florestais mediada por Agrobacterium tumefaciens e biobalística.

\begin{tabular}{|c|c|c|c|}
\hline Espécie transformada & Genes transferidos & Característica alvo & Referências \\
\hline \multicolumn{4}{|c|}{ Agrobacterium tumefaciens } \\
\hline Acacia mangium & uidA, nptII & Tolerância a geneticina e expresão do gene gus & XIE \& HONG, 2002 \\
\hline Eucalyptus camaldulensis & $\mathrm{C} 4 \mathrm{H}$ & Conteúdo de lignina & CHEN et al., 2001 \\
\hline Eucalyptus camaldulensis & cry3A, bar & Resistência a inseto e herbicida & $\begin{array}{l}\text { HARCOURT et al., } \\
2000\end{array}$ \\
\hline E. grandis $\times$ E. urophylla & Cad, nptII & Controle da lignificação & TOURNIER et al., 2003 \\
\hline Hevea brasiliensis & uidA, nptII, Mn-SOD & Controle de vírus & SOBHA et al., 2003 \\
\hline Morus Alba & nptII, gus & Resistência a canamicina & AGARWAL et al., 2004 \\
\hline Morus Alba & nptII, gus & Resistência a canamicina & $\begin{array}{l}\text { AGARWAL \& \& } \\
\text { KANWAR, 2007 }\end{array}$ \\
\hline Pinus pinaster & hpt, gus & Resistência a Higromicina B & TRONTIN et al., 2002 \\
\hline Populus alba & nptII, bar & Resistência a herbicida & $\begin{array}{l}\text { CONFALONIERI et al., } \\
2000\end{array}$ \\
\hline Populus nigra & $\mathrm{KTi}_{3}$ & Resistência a insetos & $\begin{array}{l}\text { CONFALONIERI et al., } \\
1998\end{array}$ \\
\hline Populus tremuloides & $4 C L, C A I d 5 H$, gus & Conteúdo de lignina & LI et al., 2003 \\
\hline Populus alba & Atcys, nptII & Resistência a inseto & $\begin{array}{l}\text { DELLEDONNE et al., } \\
2001\end{array}$ \\
\hline Pinus radiata & nptII, uidA, bar & Resistência a herbicida & CHARITY et al., 2005 \\
\hline \multicolumn{4}{|c|}{ Biobalística } \\
\hline Eucalyptus globulus & npt II, gus & Tolerância a canamicina e expresão do gene gus & SERRANO et al., 1996 \\
\hline Elaeis guineensis & gus & Expresão do gene gus & PARVEEZ et al., 1997 \\
\hline Pinus radiata & uidA, nptII & $\begin{array}{l}\text { Tolerância a geneticina, canamicina e expresão } \\
\text { do gene gus }\end{array}$ & WALTER et al., 1998 \\
\hline Pinus sylvestris & nptII, uidA & $\begin{array}{l}\text { Tolerância a geneticina, canamicina e expresão } \\
\text { do gene gus }\end{array}$ & $\begin{array}{l}\text { HAGGMAN } \\
\text { ARONEN, } 1998\end{array}$ \\
\hline Picea mariana & hpt, uidA & Resistência a higromicina e expresão do gene gus & TIAN et al., 2000 \\
\hline Pinus radiata, Picea abies & bar, nptII, gus & Resistência a herbicida & $\begin{array}{l}\text { BISHOP-HURLEY } \\
\text { al., } 2001\end{array}$ \\
\hline Pinus pinaster & hpt, gus & Resistência a higromicina e expresão do gene gus & TRONTIN et al., 2002 \\
\hline Pinus radiata & Cry1Ac, nptII, gus & Resistência a inseto & GRACE et al., 2005 \\
\hline Pinus roxbughii & bar, gus & $\begin{array}{l}\text { Resistência ao glufosinato de amônio e expresão } \\
\text { do gene gus }\end{array}$ & $\begin{array}{l}\text { PARASHARAMI et al., } \\
2006\end{array}$ \\
\hline Pinua taeda & cry $1 \mathrm{Ac}$ & $\begin{array}{l}\text { Resistência a Dendrolimus punctatus e } \\
\text { Crypyothelea formosicola }\end{array}$ & TANG \& TIAN, 2003 \\
\hline
\end{tabular}

Embora a lignina seja um composto de grande importância para a planta, esta representa um entrave para as indústrias de polpa de celulose, as quais necessitam lançarmão de produtos químicos poluentes e tóxicos de alto custo para fazer a sua remoção (DIOUF, 2003). O uso desses químicos encarece a produção de polpa e derivados e traz riscos potenciais ao meio ambiente (DEAN, 2005). Por essas razões, o isolamento e a caracterização de genes que codificam enzimas que desempenham papel chave na síntese dos monolignóis são alvos de estudos em espécies florestais. Essas enzimas são principalmente O-methyltransferase (OMT), 4-coumarate-CoA ligase (4CL) e cinnamyl alcohol dehydrogenase (CAD), sendo o gene cad apontado como alvo para a manipulação genética, uma vez que catalisa o passo final da síntese dos monolignóis (DIOUF, 2003).
Apesar da complexidade dessas vias, plantas transgênicas têm sido obtidas com reduzido ou alterados conteúdo de lignina (HALPIN et al., 1994). Esses autores obtiveram pela primeira vez plantas transgênicas de fumo com a composição da lignina alterada, pela expressão antisenso do gene cad. A mesma estratégia foi testada no híbrido de álamo (Populus tremula x Populus alba), no qual a atividade do gene cad foi suprimida tanto por anti-senso quanto por co-supressão (BAUCHER et al., 1996). Plantas transgênicas de álamo, obtidas a partir da introdução de um gene anti-senso da OMT, apresentaram reduzida atividade desta enzima, além de uma modificação na composição e quantidade de lignina (JOUANIN et al., 2000). Por outro lado, HU et al. (1999) obtiveram plantas transgênicas de álamo a partir da downregulation das 
enzimas 4CL e CAD. Estas plantas exibiram uma redução de $45 \%$ no conteúdo de lignina e um aumento em torno de $15 \%$ de celulose. TOURNIER et al. (2003) obtiveram plantas transgênicas do híbrido Eucalyptus grandis $\mathrm{x}$ E. urophylla, expressando o anti-senso do gene cad. Nesse experimento, os autores observaram que a atividade desse gene foi inibida em 58\% dos transformantes gerados, apresentando atividade residual da CAD de 26 a $22 \%$ em duas linhas de transformantes, especificamente, e níveis de downregulation compatíveis com alterações positivas da qualidade da madeira. Usando a estratégia Agrobacterium, LI et al. (2003) cotransformaram plantas de Populus tremuloides com os genes senso Cald5H e anti-senso 4CL. As plantas transgênicas obtidas apresentaram uma redução de 52\% no conteúdo de lignina, uma proporção 64\% maior nas subunidades syringyl/guaiacyl (S/G) e aumento de $30 \%$ na celulose.

\section{c) Resistência a insetos}

Os insetos são responsáveis por significativas perdas em inúmeras culturas, incluindo as espécies florestais. Os danos causados por estes, muitas vezes, são fatores limitantes para o crescimento e a sobrevivência das plantas (TZFIRA et al., 1998; GIRI et al., 2004). Além disso, a injúria causada ao tecido vegetal deixa as plantas suscetíveis ao ataque de microrganismos patogênicos, como vírus, fungos e bactérias, sendo necessário lançar mão de pesticidas para seu controle. Os pesticidas, além de serem tóxicos para o homem e poluírem o meio ambiente, esbarram na dificuldade de aplicação devido às extensas áreas de cultivo de florestas e pela altura das árvores, elevando, desta forma, o custo de produção (STUDARTGUIMARÃES et al., 2003).

Atualmente, encontram-se disponível um grande número de biopesticidas, os quais são efetivos no controle dos insetos, além de serem inócuos ao homem e a outros organismos. Bacillus thuringiensis (Bt) é uma bactéria que, durante a fase de esporulação, sintetiza proteínas na forma de cristais. Estes cristais são compostos por uma ou várias proteínas Cry, também chamadas de d-endotoxinas ou Insecticidal Crystal Proteins (ICPs). Tais proteínas são altamente tóxicas e específicas, por isso inócuas aos mamíferos e outros organismos (BOBROWSKI et al., 2003), sendo muito usadas na agricultura, horticultura, florestais e no controle de mosquitos em cidades, além de ser considerada uma alternativa aos agroquímicos (RANJEKAR et al., 2003). As proteínas formadoras de cristais de $B t$ agem perfurando o intestino do inseto após a sua ingestão, levando os mesmos à morte (TANG \& NEWTON, 2003).
Com o advento da engenharia genética e da biologia molecular, tornou-se possível o uso mais efetivo e racional dos genes cry de $B t$, tanto em plantas anuais de importância econômica, quanto em espécies arbóreas (RANJEKAR et al., 2003). Plantas transgênicas de Populus nigra expressando o gene de Bacillus thuringiensis foram obtidas por WANG et al. (1996). As plantas transformadas mostraram resistência a Apochemia cineraus e Lymantria disper. HARCOURT et al. (2000), por sua vez, obtiveram plantas transgênicas de Eucalyptus camaldulensis expressando o gene cry3A, mostrando resistência a larvas de Chrysophthata bimaculata, C. agricola, C. variicolis. LEROY et al. (2000) obtiveram plantas transgênica de Coffea arabica e Coffea canephora, expressando uma versão sintética do gene cry1Ac de $B t$, conferindo resistência a Perileucoptera coffella e outras Leucopteras spp. Plantas de Pinus taeda foram também transformadas através de biobalística com uma versão sintética do gene cry1Ac de Bt, aumentando a resistência a Dendrolimus punctatus e Crypyothelea formosicola (TANG \& TIAN, 2003).

Plantas, bactérias e animais apresentam uma gama de proteínas de defesa (com ação inseticida), incluindo entre estas os inibidores de proteases, os quais são ativados em resposta ao ataque de insetos. Estes inibidores representam a classe das proteínas de defesa dos vegetais melhor estudada (RANJEKAR et al., 2003), sendo que, atuando sobre as enzimas digestivas dos insetos, são consideradas uma alternativa aos genes de toxinas Bt (GIRI et al., 2004). CONFALONIERI et al. (1998) obtiveram plantas transgênicas de Populus nigra expressando o gene que codifica um inibidor de proteases do tipo tripisina kunitz (Kti3) isolado de Glycine $\boldsymbol{m a x}$ (soja). As plantas obtidas mostraram-se resistentes a Lymantria dispar e Clostera anastomosis. O gene atcys, que codifica o inibidor de proteases do tipo cisteína, foi isolado de Arabidopsis thaliana e transferido para plantas de álamo (Populus alba) via Agrobacterium. As plantas obtidas mostraram-se efetivas no controle de larvas de Chrysomela populi (DELLEDONE et al., 2001).

\section{d) Tolerância a herbicidas}

A obtenção de culturas geneticamente modificadas para a resistência e/ou tolerância a herbicidas é um dos principais sucessos da engenharia genética, uma vez que os herbicidas são considerados ferramentas essenciais da agricultura moderna. Culturas resistentes a herbicidas podem favorecer a utilização de produtos de amplo espectro, menos tóxicos e mais facilmente degradáveis no solo (BRASILEIRO \& DUSI, 1999), reduzindo o surgimento de ervas que competem 
por nutrientes, água e luz (STUDART-GUIMARÃES et al., 2003).

A resistência a herbicidas em espécies florestais é uma característica desejável tanto em área de ocorrência natural quanto em plantações manejadas, favorecendo o estabelecimento destas na fase inicial de crescimento (SÉGUIN et al., 1998). O primeiro relato sobre transformação genética em espécies florestais via Agrobacterium deve-se a FILLATTI et al. (1987). Esses autores introduziram no híbrido de álamo Populus alba X Populus grandidentata o gene aroA mutado, que codifica a enzima sintase do 5-enolpiruvil3-fosfochiquimato, a qual faz parte da via da biossíntese dos aminoácidos aromáticos. A transformação foi confirmada através de análises de Southern e Western blotting, e as plantas obtidas mostraram-se tolerantes ao glifosato. Posteriormente, BRASILEIRO et al. (1992) transformaram o híbrido Populus tremula x Populus alba com o gene crs1-1, que codifica a enzima Acetatolactase Sintase, conferindo resistência ao herbicida Clorosulfuran. Na seqüência, outras espécies de importância econômica foram transformadas com o gene bar, isolado da bactéria Streptomyces hygroscopicus e que codifica a enzima Fosfinotricina Acetiltransferase. Esse gene foi introduzido em plantaelite de Populus alba (CONFALONIERI et al., 2000), Picea abies (BRUKHIN et al., 2000), Eucalyptus camaldulensis (HARCOURT et al., 2000) e Pinus radiata (BISHOP-HURLEY et al., 2001), conferindo resistência a esses herbicidas.

e) Controle do florescimento

Os avanços obtidos sobre o controle do florescimento (esterilidade), em espécies florestais, são apontados como uma estratégia que reduz ou previne a transferência de genes de plantas transformadas para plantas sexualmente compatíveis (TANG \& NEWTON, 2003). Adicionalmente, a esterilidade poderá promover o crescimento vegetativo em árvores, uma vez que a energia consumida para a produção de órgãos reprodutivos seria investida no crescimento da planta, resultando em aumento da produção de biomassa (SÉGUIN et al., 1998). A macho-esterilidade também poderá tornar-se uma estratégia no controle de cruzamentos de espécies florestais, especialmente em alógamas, otimizando os resultados em programas de melhoramento.

Uma das principais estratégias usadas na obtenção de plantas transgênicas estéreis é a introdução e expressão de genes, os quais, colocados sob o controle de promotores específicos da região do tapetum de anteras, codificam para citotoxinas, causando a morte dos tecidos florais. Outra estratégia utilizada para se obter esta característica em plantas é suprimir ou bloquear a expressão de genes essenciais para o desenvolvimento dos órgãos reprodutivos através do silenciamento de genes obtidos pela cosupressão dos transgenes ou através da tecnologia anti-senso (MARIANI et al., 1990, citado por RISHI et al., 2001).

\section{f) Fitorremediação}

A tecnologia da fitorremediação é de grande importância, uma vez que utiliza plantas que acumulam, degradam ou removem contaminantes do solo, tornando estas áreas menos poluídas (RISHI et al., 2001). Segundo KASSEL et al. (2002), fitorremediação é um termo que pode ser usado para classificar seis diferentes métodos de remediação: fitoestabilização, fitoextração, fitodegradação, fitovolatilização, rizofiltração e aumento da biodegradação na rizosfera. Esses autores, em sua revisão, discutiram o uso de plantas do gênero Populus como as mais indicadas em aplicações comerciais de fitorremediação, sendo utilizada na remoção de metais e compostos orgânicos, como no caso do Trichloroethylene (TCE), químico (potencialmente cancerígeno) que não ocorre naturalmente no ambiente. Diferentes poluentes, principalmente metais pesados e compostos orgânicos, têm sido degradados ou acumulados por várias espécies de plantas. Por exemplo, plantas transgênicas de Arabidopsis expressando o gene merApe9 demonstraram maior resistência a íons de mercúrio $\left(\mathrm{Hg}^{2+}\right)$ durante a fase de germinação e crescimento (TZFIRA et al., 1998). Estudo similar foi realizado por RUGH et al. (1998). Nesse trabalho, plantas de álamo amarelo (Liriodendron tulipifera) foram transformadas com o gene merA, o qual codifica a mercúrio-reductase. Essas plantas foram capazes de reduzir o mercúrio de sua forma mais tóxica $\left(\mathrm{Hg}^{2+}\right)$ para sua forma menos tóxica ou volátil (Hg).

g) Árvores transgênicas: benefício ambiental, benefício agroindustrial, florestas nativas e potencialidades futuras

Alguns dos principais ganhos ambientais trazidos pela biotecnologia, através da transformação genética, serão: (i) a redução da pressão sobre os remanescentes das florestas nativas e da biodiversidade, (ii) a redução do impacto ambiental através da limpeza de áreas contaminadas pelo plantio de espécies fitorremediadoras, (iii) o uso de produtos químicos em menor quantidade, e (iv) o melhor aproveitamento de áreas degradadas, com plantios de espécies resistentes ao estresse abiótico. Adicionalmente, essas florestas, além de contribuírem 
para a produção de madeira (fonte renovável de energia), auxiliariam na proteção do meio ambiente através do seqüestro de carbono (SEDJO, 2001; WANG, et al., 2003). Por outro lado, os ganhos agroindustriais destacam-se no aumento da produção e qualidade da madeira, na resistência a insetos e a doenças, na redução de custos durante a produção e processamento da madeira, na redução do uso de químicos para a extração da celulose, na adaptabilidade das plantas, na remediação de áreas contaminadas.

O Brasil é um país com grandes extensões florestais, com cerca de 5,5 milhões de $\mathrm{km}^{2}$ de florestas, o que representa aproximadamente $10 \%$ do total destas no mundo. A floresta amazônica possui um estoque de madeira estimado em 60 bilhões de $\mathrm{m}^{3}$ e uma grande diversidade de produtos não-madeireiros, os quais estão apenas começando a ser valorizados nos mercados nacional e internacional. Além disso, abriga uma das maiores diversidades biológicas do planeta, com uma participação notável na conservação de $20 \%$ dos estoques de água doce no mundo, absorvendo ainda imensos estoques de carbono, os quais são de extrema importância na regulação do clima regional e global (VERÍSSIMO, 2006). Dessa forma, o reflorestamento com espécies nativas, aliados à exploração sustentável das mesmas, é de fundamental importância para a preservação dos ecossistemas e para a geração de benefícios socioeconômicos.

É sabido que a demanda por produtos madeireiros está vinculada ao aumento da população e ao desenvolvimento econômico. Na próxima década, espera-se que esta demanda cresça em torno de $20 \%$, requerendo que, em curto espaço de tempo, a área com plantios florestais seja aumentada, diminuindo com isso a pressão sobre os remanescentes de florestas nativas, a qual atinge taxas de 9,4 milhões ha-1 ano $^{-1}$ (BOERJAN, 2005). E se, por um lado, cresce a procura por produtos florestais, por outro cresce a preocupação e a demanda pela conservação dos ecossistemas e da biodiversidade. Dentro desse contexto, a engenharia genética assume adicional significância porque possibilita a introdução de um gene desejável em um único passo no processo de melhoramento de espécies florestais (GIRI et al., 2004). Segundo CAMPBELL et al. (2003), as espécies florestais alvos para a transformação genética são as Gimnospermas como: Pinus taeda, P. radiata, P.pinaster, Pseudotsuga menziesii, Picea abies, P. nigra e P. sitchiensis. Também as árvores do gênero Populus e seus híbridos, do gênero Eucalyptus, árvores como Quercus robur, Q. patrea e Willow. Até o momento, consideráveis avanços têm sido realizados usando-se algumas dessas espécies, como a redução ou alteração do conteúdo de lignina, o aumento da resistência a insetos e da tolerância a herbicidaso controle do florescimento, a limpeza de áreas contaminadas, entre outros. Contudo, essa tecnologia continuará desempenhando um papelchave no melhoramento de espécies florestais tendo como alvo o aumento no crescimento, forma e, qualidade da madeira, a resistência a herbívoros e a doenças, a tolerância a herbicidas, aumento de biomassa, produção de proteínas recombinantes, e preservação dos ecossistemas (VALENZUELA et al., 2006).

\section{CONCLUSÕES}

Há muitos anos, plantas cultivadas vêm sendo manipuladas geneticamente pelo homem por meio do melhoramento convencional. Através da técnica, as características de interesse determinadas por certos genes são transferidas à progênie por meio de cruzamento. Todavia, para o melhoramento de espécies florestais, esses métodos têm esbarrado em algumas limitações intrínsecas às plantas, como a redução do pool gênico, a ligação gênica, a incompatibilidade sexual e o longo ciclo de vida, tornando este processo árduo e demorado. A introdução controlada de genes exógenos nessas espécies, através de técnicas biotecnológicas, representa uma ferramenta valiosa ao melhoramento genético, garantindo ganhos expressivos na qualidade final dos produtos, em virtude de maior homogeneidade e direcionamento das propriedades da matéria-prima, fatores altamente desejáveis para as indústrias do setor florestal. A crescente demanda global desse setor, aliada à importância da preservação das florestas nativas e da biodiversidade, tornou essencial a adoção de estratégias de transformação genética para as espécies florestais.

\section{REFERÊNCIAS}

AGARWAL, S. et al. Agrobacterium tumefaciens mediated genetic transformation and regeneration of Morus alba L. Scientia Horticulturae, v.100, p.183-191, 2004.

AGARWAL, S; KANWAR, K. Comparison of genetic transformation Morus alba L. via different regeneration systems. Plant Cell Reports, v.26, n.2, p.177-185, 2007.

ANDRADE, G.M. et al. Biologia molecular do processo de infecção por Agrobacterium spp. Fitopatologia Brasileira, v.28, n.5, p.465-476, 2003.

BABU, R.M. et al. Advances in genetically engineered (transgenic) plants in pest management-an over view. Crop Protection, v.22, p.1071-1086, 2003. 
BACHA, C.J.C.; BARROS, A.L.M. Reflorestamento no Brasil: evolução recente e perspectiva para o futuro. Scientia Forestalis, n.66, p.191-203, 2004.

BAUCHER, M. et al. Red xylem and higher lignin extractabilty by down-regulation a cinnamyl alcohol dehydrogenase in poplar. Plant Physiology, v.112, p.14791490, 1996.

BAUCHER, M. et al. Lignin: genetic engineering and impact on pulp. Critical Reviews in Biochemistry and Molecular Biology, v.38, p.305-350, 2003.

BIRCH, R.G. Plant transformation: problems and strategies for practical application. Annual Review of Plant Physiology and Plant Molecular Biology, v.48, p.297-326, 1997.

BISHOP-HURLEY, S.L. et al. Conifer genetic engineering: transgenic Pinus radiata (D. Don) and Picea abies (Karst) plant are resistant to the herbicide Buster. Plant Cell Reports, v.20, p.235-243, 2001.

BOBROWSKI, V.L. et al. Genes de Bacillus thuringiensis: uma estratégia para conferir resistência a insetos em plantas. Ciência Rural, v.34, n.1, p.843-850, 2003.

BOERJAN, W. Biotechnology and the domestication of forest trees. Current Opinion in Biotechnology. v.16, p.159166, 2005.

BRASILEIRO, A.C.M.; DUSI, D.M.A. Transformação genética de plantas. In: TORRES, A.C. et al. Cultura de tecidos e transformação genética de plantas. Brasília: EmbrapaSPI/Embrapa-CNPH, 1999. Parte IV, v.2, p.679-735.

BRASILEIRO, A.C.M.; CANÇADO, G.M.A. Plantas transgênicas. Informe Agropecuário, v.21, p.28-35, 2000.

BRASILEIRO, A.C.M. et al. Expression of the mutant Arabidopsis thaliana acetolactate synthase gene confers chlorsulfuron resistance to transgenic poplar plants. Transgenic Research, v.1, p.133-141, 1992.

BRUKHIN, V. et al. Basta tolerance as a selectable and screening marker for transgenic plants of Norway spruce. Plant Cell Reports, v.19, p.899-903, 2000.

CARPANEZZI, A.A. Benefícios indiretos da floresta. In: GALVÃO, A.P.M. Reflorestamento de propriedades rurais para fins produtivos e ambientais: um guia para ações municipais e regionais. Brasília: Embrapa Floresta, 2000. Cap.2, p.19-55.

CAMPBELL, M.M. et al. Forestry's fertile crescent: the application of biotechnology to forest trees. Plant Biotechnology Journal, v.1, p.141-154, 2003.

CHALFIE, M. et al. Green fluorescent protein as a marker for gene expression. Science, v.263, p.802-805, 1994.

CHARITY, J.A. et al. Consistent and stable expression of the npt II, $\mu i d A$ and bar genes in transgenic Pinus radiata after Agrobacterium tumefaciens-transformed transformation using nurse cultures. lant Cell Report, v.23, p.606-616, 2005.
CHEN, Z.Z. et al. Plant production of transgenic Eucalyptus camaldulensis carrying the Populus tremuloides cinnamate 4hydroxylase gene. Taiwan Journal for Science, v.16, n.4, p.254-258, 2001.

COMAI, L. et al. An altered aroA gene product confers resistance to the herbicide glyphosate. Science, v.221, p.370371, 1983

CONFALONIERI, M. et al. Regeneration of Populus nigra transgenic plants expressing a Kunitz proteinase inhibitor (KTi3) gene. Molecular Breeding, v.4, p.137-145, 1998.

CONFALONIERI, M. et al. Transformation of elite white poplar (Populus alba L.) cv. 'Villafranca' and evaluation of herbicide resistance. Plant Cell Reports, v.19, p.978-982, 2000.

DEAN, J.F.D. Synthesis of lignin in transgenic and mutant plants. In: STEINBÜCHEL, A.; DOI, Y. Biotechnology of biopolymers: from synthesis to patents. Weinheim: WileyVCH Verlag, 2005. p.3-26.

DELLEDONE, M. et al. Transformation of white poplar (Populus alba L.) with a novel Arabidopsis thaliana cysteine proteinase inhibitor and analysis of insect pest resistance. Molecular Breeding, v.7, p.35-42, 2001.

DIOUF, D. Genetic transformation of forest trees. African Journal Biotechnology, v.2, n.10, p.328-333, 2003.

DUNWELL, J.M. Transgenic approaches to crop improvement. Journal of Experimental Botany, v.51, p.487-496, 2000 .

ERIKSSON, M.E. et al. Increased gibberellin biosynthesis in transgenic trees promotes growth, biomass production and xylen fiber lenght. Nature Biotechnology, v.18, p.784-788, 2000.

ELLIS, D.D. et al. Stable transformation of Picea glauca by particle acceleration. Bio/Technology, v.11, p.84-89, 1993.

FAO. Preliminary review of biotechnology in forestry including genetic modification. Forest Genetic Resources Working Paper FGR/59E. Forest Resources Development Service. Forest Resources Division. Rome, Italy, 2004, 124p.

FERREIRA, C.A.; GALVÃO, A.P.M. Importância da atividade florestal no Brasil. In: GALVÃO, A.P.M. Reflorestamento de propriedades rurais para fins produtivos e ambientais: um guia para ações municipais e regionais. Brasília. Embrapa Floresta, 2000. Cap.1, p.15-18.

FERREIRA, M.; SANTOS, P.E.T. Melhoramento genético florestal dos Eucalyptus no Brasil: breve histórico e perspectivas. In: IUFRO Conference on Silviculture and Improvement of Eucalypt. Colombo: Embrapa-CNPF, 1997. p.14-34.

FILLATTI, J.J. et al. Agrobacterium mediated transformation and regeneration of Populus. Molecular and General Genetics, v.206, p.192-199, 1987.

GARTLAND, K.M.A. et al. Genetically modified trees: producton, properties, and potential. Journal of Arboriculture, v.29, n.5, p.259-266, 2003 
GELVIN, S.B. Agrobacterium and plant genes involved in TDNA transfer and integration. Annual Review of Plant Physiology and Plant Molecular Biology, v.51, p.223-256, 2000.

GIRI, C. et al. Progress in tissue culture, genetic transformation and application of biotechnology to trees: an overview. Trees, v.18, n.2, p.115-135, 2004.

GRACE, L.J. et al. Insect-resistant transgenic Pinus radiata. Plant Cell Reports, v.24, n.2, p.103-111, 2005.

HAGGMAN, L.; ARONEN, T. Transgene expression in regenerating cotyledons and embryogenic cultures of Scots pine. Journal of Experimental Botany, v.49, p.1147-1156, 1998.

HALPIN, C.; BOERJAN, W. Stacking transgenes in forest trees. Trends in Plant Science, v.8, n.8, p.363-365, 2003.

HALPIN, C. et al. Manipulation of lignin quality by downregulation of cinnamiyl alcohol dehydrogenase. Plant Journal, v.6, p.339-350, 1994.

HANSEN, G.; WRIGHT, M.S. Recent advances in the transformation of plants. Trends in Plant Science, v.4, n.6, p.226-231, 1999.

HARCOURT, R.L. et al. Insect and herbicide-resistant transgenic Eucalyptus. Molecular Breeding, v.6, p.307-315, 2000 .

HERRERA-ESTRELLA, L. et al. Chimeric genes as dominant selectable markers in plant cells. EMBO Journal, v.2, p.987995, 1983.

HU, W.J. et al. Repression of lignin biosynthesis promotes cellulose accumulation and growth in transgenic trees. Nature Biotechnology, v.17, p.808-812, 1999.

JEFFERSON, R.A. et al. GUS fusions: ß-glucuronidase as a sensitive and versatile gene fusion marker in higher plants. EMBO Journal, v.6, p.3901-3907, 1987.

JOUANIN, L. et al. Lignification in transgenic poplarwith extremely reduced caffeic acid O-methyl transferase activity. Plant Physiology, Rockville, v.123, p.13631374, 2000.

JUVENAL, T.L.; MATTOS, R.L.G. O setor florestal no Brasil e a importância do reflorestamento. BNDS Setorial, n.16, p.3-30, 2002.

KASSEL, A.G. et al. Phytoremediation of trichloethylene using hybrid Poplar. Physiology Molecular Biology Plant, v.8, n.1, p.3-10, 2002.

KLEIN, T.M. High-velocity microprojectiles for delivering nucleic acids into living cells. Nature, v.327, p.70-73, 1987.

LACORTE, C.; ROMANO, E. Transferência de vetores para Agrobacterium. In: BRASILEIRO, A.C.M.; CARNEIRO, V.T. (Org). Manual de transformação genética de plantas. Brasília: SPI/Embrapa, 1998. V.1, p.93-109.

LADEIRA, H. Quatro décadas de Engenharia Florestal no Brasil. Sociedade de Investigação Florestal. Viçosa, 2002. 207p.
LEROY, T. et al. Genetically modified coffee plants expressing the Bacillus thuringiensis cry1AC gene for resistance to leaf miner. Plant Cell Reports, v.19, p.382-389, 2000.

LI, L. et al. Combinatorial modification of multiple lignin traits in trees through multigene cotransformation. Plant Biology, v.100, n.8, p.4939-4944, 2003.

MORA, A.L.; GARCIA, C.H. Eucalypt cultivation in Brazil. São Paulo: Sociedade Brasileira de Silvicultura, 2000. 112p.

MROGINSKI, L. et al. Establecimento de cultivos de tejidos vegetales. In: ECHENIQUE, V. et al. Biotecnologia y mejoramiento vegetal. INTA: Consejo Argentino para la Información y el Desarrollo de la Biotecnologia, 2004. p.3542.

NORELLI, J.L.; ALDWINCKLE, H.S. The role of aminoglycoside antibiotics in the regeneration and selection of neomycin phosphotransferase-transgenic apple tissue. Journal American Society Horticultural Science, v.118, p.311316, 1993.

PARASHARAMI, V.A. et al. Stable transformation of mature zygotic embryos and regeneration of transgenic plants of chir pine (Pinus roxbughii Sarg.). Plant Cell Reports, v.24, p.708714, 2006.

PARVEEZ, G.K.A. et al. Physical parameters affecting transient GUS gene expression in oil palm (Elaeis guineensis Jacq.) using the biolistic device. Industrial Crops and Products, v.6, p.41-50, 1997.

PASQUALI, G.; ZANETTINI, M.H.B. Transgênese florestal. In: BORÉM, A. Biotecnologia florestal. Viçosa: UFV. 2007. Cap. 14, p.317-334.

POUPIN, M.; ARCE-JOHNSON, P. Transgenic trees for a new era. In Vitro Cell Development Biology Plant, v.41, p.91101, 2005.

RANJEKAR, P.K. et al. Genetic engineering of crop plants for insect resistance. Current Science, v.84, p.101-110, 2003.

RECH, E.L.; ARAGÃO, F.J.L. Biobalística. In: BRASILEIRO, A.C.M.;CARNEIRO, V.T.C. Manual de transformação genética de plantas. Brasília. Embrapa/SPI, 1998. Cap.3, p.51-64.

RISHI, A.S. et al. Improvement of Populus through genetic engineering. Indian Journal Plant Physiology, v.6, n.2, p.119-126, 2001.

RUGH, C.L. et al. Development of transgenic yellow poplar for mercury phytoremediation. Nature Biotechnology, v.16, p.925-928, 1998.

SANFORD, J.C. et al. Delivery of substances into cells tissues using a particle bombardment process. Journal Particulate Science Technology, v.5, p.27-37, 1987.

SEDJO, R.A. Biotechnology in forestry. Resources For the Future. Washington: RFF. p. 10-12, 2001.

SÉGUIN, A. et al. Transgenic trees. In: BRUCE, A; PALFREYMAN, J.W. Forest products biotechnology. London: Taylor \& Francis, 1998. Cap. 18. p. 287-303. 
SERRANO, L. et al. Genetic transformation of Eucalyptus globulus through biolistics: complementary development of procedures for organogenesis from zygotic embryos and stable transformation of corresponding proliferating tissue. Journal of Experimental Botany, v.47, p.285-290, 1996.

SOBHA, S. et al. Genetic transformation of Hevea brasiliensis with the gene coding for superoxide dismutase with FMV 34S promoter. Current Science, v.85, n.12, p.1767-1773, 2003.

STRAUSS, S.H. et al. Genetic enginering of reproductive sterelity in forest trees. Molecular Breeding, v.1, p.5-26, 1995.

STUDART-GUIMARÃES, C. et al. Transformação genética em espécies florestais. Ciência Florestal, v.13, n.1, p.167178, 2003.

TANG, W.; NEWTON, R.J. Genetic transformation of conifers and it application in forest biotechnology. Plant Cell Report, v.22, p.1-15, 2003.

TANG, W.; TIAN, Y. Transgenic loblolly pine (Pinus taeda L.) plants expressing a modified $\delta$-endotoxin gene of Bacillus thuringiensis with enhanced resistance to Dendrolimus punctatus Walker and Crypyothelea formosicola Staud. Journal of Experimental Botany, v.54, n.383, p.835-844, 2003.

TIAN, L.N. et al. Hygromycin resistance is an effective selectable marker for biolistic transformation of black spruce (Picea mariana). Plant Cell Reports, v.19, p.358-362, 2000.

TOURNIER, V. et al. An efficient procedure to stably introduce genes into an economically important pulp tree (Eucalyptus grandis x E. urophylla). Transgenic Research, v.12, n.4, p.403-411, 2003.

TRONTIN, J.F. et al. Towards genetic engineering of maritime pine (Pinus pinaster Ait.). Annual of Forest Science, v.59, p.687-697, 2002.
TZFIRA, T.; CITOVSKY, V. From host recognition to T-DNA integration: the function of bacterial and plant genes in the Agrobacterium plant cell interaction. Molecular Plant Pathology, v.1 p.201-212, 2000.

TZFIRA, T. et al. Forest-tree biotecnology: genetic transformation and its application to future forests. TIBTECH, v.16, p.439-446, 1998.

VALENZUELA, S. et al. Transgenic trees and forestry biosafety. Electronic Journal Biotechnology, v.9, n.3, p.335-339, 2006.

VERÍSSIMO, A. Estratégias e mecanismos financeiros para florestas nativas no Brasil. 2006. Capturado em 10 abr. 2007. On line. Disponível na Internet: http:// www.docpark.net/FAO-fo/Esp/Nativa_Brasil_ Fev06_final_1.pdf.

WALTER, C. et al. Stable transformation and regeneration of transgenic plants of Pinus radiata D. Don. Plant Cell Reports, v.17, p.460-468, 1998.

WANG, G. et al. Poplar (Populus nigra L.) plants transformed with a Bacillus thuringiensis toxin gene: insecticidal activity and genomic analysis. Transgenic Research, v.5, p.289301, 1996.

WANG, W. et al. Plant responses to drought, salinity and extreme temperatures: towards genetic engineering for stress tolerance. Planta, v.218, n.1, p.1-14, 2003.

XIE, D.Y.; HONG, Y. Agrobacterium-mediated genetic transformation of Acacia mangium. Plant Cell Reports, v.20, p.917-922, 2002.

ZUPAN, J. et al. The transfer of DNA from Agrobacterium tumefaciens into plants: a feast of fundamental insights. Plant Journal, Oxford, v.23, p.11-28, 2000. 